Volume 11, Issue 4, October 2020: 436-457

DOI: 10.17569 / tojqi. 775926

Research Article

\title{
The Formation of Subjectivity in Asian Students in Japanese Higher Education ${ }^{1}$
}

\author{
Tomoka Sato ${ }^{2}$
}

\begin{abstract}
This paper explores how non-Japanese Asians studying at Japanese universities form their subjectivity and negotiate in Japanese society. To this end, a qualitative paradigm, namely a narrative approach to data collection, was employed as a methodological framework, and the data collection methods were face-to-face interviews and social media. The participants were six Asian students from different Asian countries. After collecting their narratives and transcribing them, I categorized them into three phases: Expectations \& Gaps, Outcomes, and Vision for the future. The findings reveal that all participants felt admiration and respect for Japanese perseverance and politeness, as well as Japan's advanced technology in their imaginary world before they came to Japan. However, after living in Japan, this view changed to a negative one, leaving them disappointed by Japanese narrowmindedness and both invisible and visible discrimination against them. These negative experiences gradually created their subjectivity as they have found themselves trying to conform to Japanese social power and norms and acting like the Japanese while in Japan. However, their hearts were no longer in Japan. These findings imply that Japanese students' intercultural understanding is dominated by the cultures of the English-speaking world, while their understanding of other cultures except for those of that world is scant. The paper concludes by suggesting a cosmopolitan pedagogy for intercultural understanding and communication so that Japanese students can become true global citizens.
\end{abstract}

Keywords: Asian students in Japanese Higher Education, subjectivity, intercultural understanding.

\footnotetext{
${ }^{1}$ The data in this study were gathered before 2020 and within the scope of a doctoral research accepted by the Research Ethics Committee of University College London on 08.01.2016.

${ }^{2}$ Dr., Temple University, Japan Campus, tomoka.sato@tuj.temple.edu, https://orcid.org/0000-0002-3430-2010
}

Received: 30.07.2020, Accepted: 21.10.2020 


\title{
Japon Yükseköğretiminde Asyalı Öğrencilerde Öznelliğin Oluşumu
}

\begin{abstract}
$\ddot{\mathbf{O} z}$
$\mathrm{Bu}$ çalışmanın amacı, Japon üniversitelerinde okuyan Japon olmayan Asyalıların Japon toplumunda öznelliklerini nasıl oluşturduklarını ve müzakere ettiklerini araştırmaktır. Bu amaçla çalışmada, Çalışma, nitel araştırma desenlerinden biri olan "anlatı araştırması" deseni kullanılmıştır. Çalışmada veriler, yüz yüze görüşmeler ve sosyal medya aracılığıyla toplanmıştır. Çalışmanın katılımcıları, farklı Asya ülkelerinden altı Asyalı öğrenciden oluşmaktadır. Öğrencilerin anlatıları toplandıktan ve yazıya döküldükten sonra üç aşamaya ayrılmıştır: Beklentiler ve Boşluklar, Sonuçlar ve Gelecek için Vizyon. Bulgular, tüm katılımcıların Japonya'ya gelmeden önce hayali dünyalarında Japonya'nın ileri teknolojisinin yanı sıra Japon azmi ve nezaketine hayranlık ve saygı duyduklarını ortaya koymaktadır. Bununla birlikte, Japonya'da yaşadıktan sonra, bu görüş olumsuz bir görüşe dönüşmüştür. Katılımcıaalr Japonların dar görüşlü olduklarını ve yabancılara karşı hem görünmez hem de görünür ayrımcılık yaptıklarını ileri sürerek hayal kırıklığına uğradıklarını ifade etmişlerdir. Kendilerini Japon sosyal gücüne ve normlarına uymaya çalışırken ve Japonya'da Japonlar gibi davranmaya çalışırken bulduklarını ifade eden katılımcılar bu olumsuz deneyimlerin kademeli olarak öznelliklerini yarattığını belirtmişlerdir. Bu bulgular, Japon öğrencilerin kültürlerarası anlayışının İngilizce konuşulan dünyanın kültürleri tarafından yönetildiğini, ancak o dünyadaki kültürler dışındaki diğer kültürleri anlamalarının yetersiz olduğunu göstermektedir. Makalenin sonuçlarına göre Japon öğrencilerin gerçek küresel vatandaşlar olabilmeleri için kültürlerarası anlayış ve iletişim için Japon yükseköğretimine kozmopolit bir eğitim önermektedir.
\end{abstract}

Anahtar Sözcükler: Japon Yükseköğretiminde Asyalı ögrenciler, öznellik, kültürlerarası anlayış. 


\section{Introduction}

In 2014, the former Japanese Prime Minister Shinzo Abe announced a major reform of higher education; the Top Global University Project. The purpose of this project is to enhance the international competitiveness of higher education in Japan and to internationalize Japanese universities. Referring to the Times Higher Education World University Rankings, the former Prime Minister Abe stated that "the number of foreign students in university will define its success" (East Asia Forum, 2014). One of the tools to be used to achieve this goal was to attract foreign students. The project has its own budget. The universities, whether public or private, collaborated by deciding to conduct promotional activities to invite foreign students to their campuses. As a result, the number of foreign students in universities designated by The Japanese Ministry of Education, Culture, Sports, Science, and Technology (hereafter MEXT) has increased dramatically over the past five years. Although these universities have been receiving students from different parts of the world, students are predominantly from geographically and culturally close Asian countries. With the enforcement of this reform, statistical data on these students were collected by MEXT and the Japan Students Service Organization (JSSO). However, what is notably absent from these data is any attention being given to them from a qualitative perspective. In particular, how these individuals experience and interact with their social world and how major contextual factors such as social and political factors affect the ways in which their subjectivities are formed remain unexplored. Examining these aspects is important if classrooms are to become globalized in a real sense. Simply collecting numbers of foreign students does not demonstrate that Japanese universities have become international. Unless these students' status within Japan is understood, it will be impossible to declare the Global Project successful.

In this case study, I therefore investigate qualitatively the experiences of six undergraduate students from different Asian countries. In addition to examining empirical materials including scheduled face-to-face and impromptu interviews via SNS, this case study employs Foucault's (1980) conceptualization of the relationship between power, subjectivity, and agency to reveal how Asian students studying in Japanese universities form their subjectivities and negotiate within Japanese society. 


\section{Top Global University Project: A Brief Overview}

The Top Global University Project (TGUP) is a government-funded project that started in 2014 and is slated to continue to 2023. MEXT provides financial support for universities that are making substantial efforts to internationalize by building and enhancing partnerships and exchange programs with world-leading universities. Reforms to personnel and administrative structures, educational systems, and environmental infrastructure designed to foster students' ability to deal with globalization are also included. MEXT adopted a two-track approach to the project. Type A designates world-class universities that have the potential to be ranked in the top 100 in world universities rankings, while Type B represents universities that attempt to create an innovative curriculum and programs that will contribute to the move of Japanese society toward globalization. In September 2014, MEXT announced the selection of universities for the TGUP, designating 13 universities as Type A and 24 as Type B out of 109 applying universities. Broad criteria for selection were based on internationalization, governance, and educational reform. For example, the specific criteria for internationalization, for instance, were:

1. Percentage of international full-time faculty staff and [domestic] full-time faculty staff who have received their degrees at a foreign university

2. Percentage of international students

3. Percentage of Japanese students who have experienced credit earning study abroad

4. Percentage of Japanese students studying abroad under inter-university agreements

5. Percentage of classes conducted in foreign languages

6. Percentage of students enrolled in degree programs in foreign languages

7. Percentage of students who meet foreign language standards

8. Percentage of syllabus translated into English

9. Percentage of Japanese students who stay in international dormitories

10. Flexible academic calendar

(MEXT: Top Global University Project)

I teach in both Type A and B universities, and I have observed the number of international students increasing year by year. The case study presented in this paper draws on the experiences of six undergraduate members of the Asian cohort. In examining this particular group of students, I explore not only the experiences in Japan of Asian students but also whether TGUP performs well in terms of intercultural communication between Japanese and other Asian 
students. However, it is not my intention to evaluate the intentions of policymakers or the decisions made regarding implementation of the project. Indeed, in terms of outcomes, the project has brought about sweeping, positive changes. For instance, Japanese students now have more opportunities to immerse themselves in English environments without having to study abroad.

\section{Literature Review}

Whereas many studies have focused on Asian students studying in English-speaking countries (e.g., Benson, Barkhuizen, Bodycott, \& Brown, 2012, 2013; Block, 2006; Churchill, 2009; Jackson, 2008; Piller \& Takahashi, 2006; Sato, 2014, 2015), few studies have examined the position of Asian students studying in Japanese universities, especially from a qualitative perspective. In the context of intercultural communication, individual's agency and will, i.e., the ability and will of an individual to act in a given environment, more precisely, "the ability to be willing to be open to Others and the world and the ability to engage in cosmopolitan action" (Sobré-Denton \& Bardhan, 2013, p. 68) are mainly focused. However, how this agency is determined tends to be neglected. Therefore, this section reviews Foucault's (1980) conceptualization of the relationship between power, subjectivity and agency, and it will function as the theoretical framework for this study.

\section{Relationship Between Power, Subjectivity and Agency}

Foucault (1980) developed a novel way of conceptualizing power. In general, the prevalent conception of power is what Foucault labels "juridical power." Traditionally, this power is based on the rule of law and presupposes power relations between a sovereign and subjects whereby a sovereign imposes his will on his subjects. In this context, power is seen as operating within the State. As long as the exercise of power is viewed as the imposition of the will of a powerful individual on that of a powerless one, power is interpreted as a restrictive, repressive, and negative force. Foucault argues that this power should be viewed in terms of "an essentially negative power, presupposing on the one hand a sovereign whose role is to forbid and on the other a subject who must somehow effectively say yes to this prohibition" (1980, p. 140). 
However, Foucault extends his analysis of power by challenging this notion of power as sovereignty. Foucault critiques its assumption that power is restricted to the relation between a sovereign and subjects by law. Insofar as power is viewed in this way, it is assumed that wherever subjects are out of the reach of the sovereign, they are free from power. Foucault denies this kind of domination, that is, one person exercising power over others, or one group doing so over another. Instead he argues that there exists non-sovereign power, which he defines as "disciplinary power" (p.105), and which lies outside of sovereignty. Foucault thus views power as

"the manifold forms of domination that can be exercised within society. Not the domination of the King in his central position, ... but that of his subjects in their mutual relations: not the uniform edifice of sovereignty, but the multiple forms of subjugation that have a place and function within the social organism." (p. 96)

From this perspective, the analysis of power

"should not concern itself with the regulated and legitimate forms of power in their central locations, with the general mechanisms... On the contrary, it should be concerned with power at its extremities, ... that is, in its more regional and local forms and institutions." (p. 96)

Foucault argues that the peripheral relations of domination and subjugation that are obscured by a narrow focus on juridical power should be paid more attention. For Foucault, juridical power is only partial and narrow as it views power simply as an essentially negative, repressive, and prohibitive force. In this context, "Power is what says no" (p.139). Foucault explained this view in a 1977 interview as follows:

"If power were never anything but repressive, if it never did anything but to say no, do you really think one would be brought to obey it? What makes power hold good, what makes it accepted, is simply the fact that it doesn't only weigh on us as a force that says no, but it traverses and produces things, it induces pleasure, forms knowledge, produces discourse. It needs to be considered as a productive network which runs through the whole social body, much more than as a negative instance whose function is repression." (Foucault, 1980, p. 119)

Foucault thus views power as ubiquitous and both repressive and productive. However, this does not mean that Foucault ignores juridical power, which views power as sovereign and repressive, and replaces it with what he defines as "disciplinary power," which views power as 
peripheral and productive. Indeed, he argues that power "doesn't only [italic added] weigh on us as a force that says no" (1980, p.139). Both juridical (repressive) and disciplinary (productive) power, he explains, coexist in contemporary Western societies, and the individual subject is one of the primary effects of this repressive and productive power. According to Foucault, if power is always and only viewed as being exercised over individual subjects who are subject to the power of the sovereign, this conception of the individual suggests "an elementary nucleus, a primitive atom, a multiple and inert material" (p. 98). Thus, Foucault argues that as juridical power delimits our actions, individuals are fully formed and stable entities that get caught up in power relations.

However, Foucault also argues that individual subjects do not come into the world fully formed. Rather, they are constituted in and through social relations, which entails power. Thus, power plays a key role in forming individual subjects. According to Foucault, individual subjects are subjected to shifting power relations within their society and can choose the position of subject within these power relations. In other words, for Foucault, power determines individual subjectivity, stating that:

"In fact, it [the individual] is already one of the prime effects of power that certain bodies, certain gestures, certain discourses, certain desires, come to be identified and constituted as individuals... The individual is an effect of power." (p. 98)

As Foucault uses the term "subjectivity" and "agency" interchangeably, he does not draw a sharp distinction between these two terms. However, this statement can be interpreted that subjectivity determines agency, the ability or capacity to act in a given environment. That is, on the basis of an individual's beliefs, consciousness, biases, interpretations, feelings, or imaginings, the individual may have the ability to act. Thus, if power determines individual subjectivity, it follows that individual subjectivity also determines agency. As Foucault argues,

"It [the exercise of power] is a total structure of actions brought to bear upon possible actions; it incites, it induces, it seduces, it makes easier or more difficult; in the extreme it constrains or forbids absolutely: it is nevertheless always a way of acting upon an acting subject or acting subjects by virtue of their acting or being capable of action." (Foucault, 1982, p. 789)

In a nutshell, Foucault argues that power operates within society and determines individual subjectivity, which results in developing agency. In this way, power not only constrains but 
also enables human action.

\section{Methodology}

In this study, I adopt a qualitative paradigm. This choice is underpinned by Merriam's (2002) definition of qualitative research, which is based on the idea that "meaning is socially constructed by individuals in interaction with their world" (p. 3), and is suitable for researchers interested in "[1] earning how individuals experience and interact with their social world, the meaning it has for them" (p. 4) and in investigating how major contextual factors such as social and political factors affect how individuals construct reality. More specifically, narrative inquiry is the best way of representing and understanding experiences that are difficult to observe directly and are best understood from the perspectives of those who experience them. According to Lather (1992), narrative inquiry can be categorized into three theoretical paradigms: understanding (interpretive), emancipating (critical and feminist perspectives being included), and deconstructing (postmodern). As my focus in this study is not simply to understand Asian students studying in Japan but to also critique Japanese students' prejudices due to their indifference to and ignorance of other cultures, my theoretical stance as regards methodology is critical as well as interpretive. Data ${ }^{2}$ will consist of my participants' narratives, especially first-person accounts of their experiences. My decision to employ narrative analysis is also supported by Riessman (2008), who argues that,

"A good narrative analysis prompts the reader to think beyond the surface of a text, and there is a move toward a broader commentary. Just because narrative approaches interrogate cases (rather than population-based samples), it cannot be generalized. But inference is of a different kind.... Making conceptual inferences about a social process (the construction of an identity group, for example, from close observation of one community) is an equally "valid" kind of inquiry with a long history in anthropology and sociology.” (p. 13)

\section{Data Collection}

There were six student participants: three males, and three females (Table 1). All participants studied in a university in Tokyo and came from Asian countries. All of them were my students. They were selected for this study on the basis of their willingness to participate. All names are pseudonyms. 
Table 1

Participants' backgrounds

\begin{tabular}{llll}
\hline Name & Home Country & Gender & Age \\
\hline Yuan & Malaysia & F & 20 \\
Thao & Vietnam & M & 24 \\
Yong-ha & South Korea & M & 20 \\
Seung & South Korea & F & 20 \\
Xia & China & F & 22 \\
Tu & Taiwan & M & 20 \\
\hline
\end{tabular}

The data in this study were gathered within the scope of a doctoral research accepted by the Research Ethics Committee of University College London on 08.01.2016.

\section{Method}

The interviews were my main data collection method since the purposes of this research were to explore the views, experiences, beliefs and motivations of individuals. Interviews are believed to provide a deeper understanding of social phenomena than would be obtained purely quantitative methods such as questionnaires. To collect narrative data from the participants, face-to-face and one-on-one semi-structured interviews were conducted between April 2016 and May 2018 in Tokyo. The interviews were carried out in a relaxed manner and held at times and in places convenient to the participants on the university campus we all belong to. I conducted the interviews based on Seidman's (2006) model for "in-depth, phenomenologically based interviews" (p. 15). Seidman suggests three 90-minute interviews separated by several days' intervals, which allows both interviewer and participant to understand the experience and to place it in context. However, considering the participants' and my own schedule, it was necessary to adjust the number of interviews held for this study. Some participants had an inperson interview only once, but their interviews were complemented by email and SNS. I tried to follow the progression on Seidman's (2006) protocol. The interviews were conducted as follows. First, the participants were asked to give biographical details. Second, they were asked to describe how they live their lives and their personal feelings toward each event recounted. Third, they were asked to reflect on their social experiences to examine how these are connected to their present lives. Finally, they talked about what they envisaged doing in the future. Following Seidman, I tape-recorded all interviews. Seidman describes benefits of tape- 
recording as follows: First, in order that the researcher may transform spoken words into a written text to examine, tape-recording is most reliable. Second, preserving the words of the participants allows the researcher to work from original data as the researcher can return to the source and check for accuracy whenever necessary. Tape-recording also benefits the participants. The fact that what they have said is recorded can give them confidence that their words will be treated valuably and responsibly. In addition, it also allows participants to decide what in the recording they choose to retain and what they wish to delete.

\section{Data Organization and Processing}

A key criterion for evaluating the quality of research data and analysis concerns its "reliability", defined by Thomas (2013) as "the extent to which a research instrument such as a test will give the same result on different occasions" (p.138) and by Gall et, al. (2003) as "the extent to which other researchers would arrive at similar results if they studied the same case using exactly the same procedures as the first researcher" (p.635). Both Thomas and Gall et, al. take a relatively positivist perspective. However, my theoretical position, an interpretive perspective as mentioned above disputes "the assumption that there is a single reality and that studying it repeatedly will yield the same results" (Merriam, 1998, p.205). In interpretive qualitative research,

"Researchers seek to describe and explain the world as those in the world experience it. Since there are many interpretations of what is happening, there is no benchmark by which to take repeated measures and establish reliability in the traditional sense" (Merriam, 1998, p.205).

Namely, the notion that reliable procedures will lead to predictable or uniform outcomes is flawed.

However, this does not mean that the way data is collected, handled and presented lacks rigorous. Instead of reliability, the validity of the interview data arises from its "authenticity" (Scott, 1990, p.6), which is related to the accuracy and honesty of the data. In this respect, I adopted an audit trail approach to illustrate that findings are based on the participants' narratives instead of my own preconceptions and biases and establish the confirmability of this study's findings. Validity is divided into two categories: internal and external. "Internal validity seeks to demonstrate that the explanation of a particular event, issue or set of data which a 
piece of research provides can actually be sustained by the data" (Cohen et al., 2011, p.183). That is, the extent to which the written findings are evidently generated from the data and their analysis, whereas "external validity refers to the degree to which the results can be generalized to the wider population, cases, times or situations, i.e. to the transferability of the findings" (p.186). As this study focuses on the experiences and perspectives of a small number of participants, external validity is not established. However, given the varied sources from which analysis draws, the findings may have implications for Japanese students who do not exactly know what intercultural understanding is and for university courses in which students from different Asian countries study.

Thus, in order to establish internal validity, I followed Nagatomo's (2012) transcription method for interviews. I transcribed each interview from audio recordings immediately after the interview. First, I verbatim transcribed all that include hesitant phrases and fillers sounds, such as "um”, “like”, “you know”, "I mean”, “actually”, "basically” and so on, as well as any codeswitching into Japanese or English. Then, retaining this copy, I created a refined version of the transcription, in which hesitant phrases, filler sounds, and grammatical errors were eliminated as my study focuses on what is said rather than how, to whom, or for what purpose it was said. This second version was sent to the participants immediately after each interview, which enabled them to review detailed interview responses (member checking) and verify the interpretive accuracy. To assure internal validity, member checking is one of the strategies (Simon and Goes, n.d.).

All excerpts included here were originally a mix of Japanese and English, but I translated them into English for readability in the analysis and interpretation section that follows. I tried to keep the participants' narratives as close as possible to the original with a focus on what they said, but eliminated fillers sounds and modified grammatical mistakes such as verb tense and form. Finally, I invited an academic who know both Japanese and English to check my translation, which helped increase the quality of research data.

\section{Analysis}

As my interest was the participants' emotional attitudes toward Japan and Japanese people before and after living in Japan, I focused on changes in such attitudes as well as what factors 
caused these changes. Therefore, I had pre-determined to divide the participants' narratives into three phrases (themes): Expectations \& Gaps, Outcomes, and Vision for the future. Polkinghorne's (1995) describes two types of approaches to data analysis: narrative analysis and analysis of narratives. According to his definition (pp. 5-6), "narrative analysis" refers to "studies whose data consist of actions, events, and happenings but whose analysis produces stories." In this approach, the data (interview transcript) is treated as non-narrative data since the data is not yet in story form. In contrast, "analysis of narratives" refers to "studies whose data consist of narratives or stories but whose analysis produces paradigmatic typologies or categories." This approach is called "thematic," "content," or "grounded theory" analysis. Given this distinction, the first phase in my data analysis was "narrative analysis," in which I turned participants' fragmented narratives on the interview transcript into stories. However, in the case that short extracts from interviews in which the participants told stories, for instance, they were treated as narrative data. The second phase of my data analysis was an "analysis of narratives," in which I used participants' narratives refined into stories (and short extracts) as data and categorized them into three themes in accordance to each phase as mentioned above.

\section{Findings}

\section{Student Perspectives: Expectations and Gaps}

Upon arriving in Japan, all the students in this study had high hopes for their sojourn and imagined that they would get along with Japanese people in addition to developing their command of Japanese. Yuan elaborated on her expectations as follows:

"I guess we all had only a positive image of Japanese people, especially due to the fact that even when the Great East Japan Earthquake occurred in 2011, disaster victims were well-behaved and patiently queued for the hot meals provided. No looting and the state of lawlessness and disorder that often comes with disasters were have seen. Therefore, I respected them and looked forward to having Japanese friends."

Likewise, Thao expressed his expectation of making friends with Japanese people.

“Many Vietnamese people appreciate Japan's financial support for economic reforms in Vietnam. As the remarkable recovery of postwar Japan caught the attention of the Vietnamese, we respect the industriousness of the Japanese people. As for me, while I was writing my bachelor's thesis in Vietnam, I became interested 
in advanced Japanese technology, especially car suspensions. Then I wanted to work with Japanese people in the field of science and technology in Japan."

Before they studied in Japan, these students had never visited Japan or had any Japanese friends in their country. They found out about Japan and Japanese people only through mass media. They thought well of Japanese people in their imaginary world.

In reality, Japanese discrimination against them was contrary to their expectations. Only after living in Japan did they experience Japanese narrow-mindedness toward other Asians on many occasions. Yuan lamented this.

At first, Japanese classmates were friendly, and I got along with them in and out of the classroom, but as the months went by, they avoided me and formed a clique and only hung out with one another. Eventually I was excluded from them. I don't know why they changed their attitude toward me, but I am not shy at all. Whenever I have questions and opinions, I always raise my hand without any hesitation. I assume that for them, I might look as if I were confident and showing off my ability, which may have annoyed them... I don't know... Some classmates are returnees ${ }^{3}$ from Englishspeaking countries, so they are supposed to be used to the way I do things. But even they don't talk to me anymore now."

Yuan did not know about Japanese society, in which "Tall trees catch much wind." She behaved in exactly the same fashion as she had done in her country, Malaysia. She had learned from her mother, who is a teacher in Malaysia, that conforming to Western values is to become a global citizen, so she did not hesitate to express what she thinks, nor did she care about how her classmates saw her. Meanwhile, although Japanese universities have adopted global standards in many ways, many Japanese students still seem to her to be unfamiliar with other Asian countries, which invites bias against them and leads to acts of discrimination. In addition to this experience in university, she was also discriminated against by a Japanese person in more obvious way in her part-time workplace, which is an amusement park.

"I was having OJT (on-the-job training) at the Information Center inside the theme park. While my trainer went away for a few minutes, an incident occurred. An old man came up to me, saying that he wanted a stamp for his parking ticket, which is

\footnotetext{
${ }^{3}$ The term "returnee" refers to persons who return to the country where they were born after living or spending a substantial amount of time elsewhere.
} 
one of the services for the customers who come to the theme park. They can get a few hours of free parking with the stamp. However, I misunderstood him and gave him the wrong information. Shortly after, he found out that this information was wrong. He came back to me with a furious look on his face, looked at my name tag, which said "Yuan" and shouted at me: "Go back to China if you don't understand such easy Japanese! We don't need gaijin 4 [foreigners] like you!!" I thought that if I had not used my Chinese name, he wouldn't have spoken that way."

Yuan could do nothing but kept apologizing and felt sad to see such overt discrimination in Japan despite the fact that Japan is a developed country. As she had several experiences of being taken for Chinese and discriminated against by Japanese people because of it, she stopped reading Chinese novels in public places. She wanted Japanese people to see her as Malaysian. In fact, she would rather be mistaken for Japanese than be identified as mainland Chinese, whom many Japanese people dislike and criticize. She described Japanese chauvinism as follows:

"After all, Japanese people have a prejudice against foreigners, especially other Asians. I am Asian, but I speak Japanese well (if I may say so), so I have Japanese friends, but still, the Japanese are too much patriotic. I don't like Japanese supporters in the Olympics, for instance. The way they support Japanese athletes exactly shows their chauvinism."

Before she came to Japan, Japan had long been her passion. But once she lived in Japan, she realized that while Japan may be the best place to visit as a traveler, living in Japan as a foreigner is not. A Korean male student, Yong-ha also expressed his disappointment over Japanese bias against other Asian people, especially Chinese and Korean.

"Whenever my Japanese coworkers in my part-time workplace, a café, see Chinese customers coming in, they immediately say: "Here are noisy Chinese again! They have bad manners. "I wanted to say that all Chinese people are not necessarily rude or impudent, because I am also prejudiced by many Japanese people. I was a bit scared to think something like that was being said behind my back."

Yong-ha realized that Japanese people have a limited view of foreigners. As a result, they judge them based on a stereotype. He thought that his own country, Korea, is similar to Japan in this respect, which disappointed his hope of studying in Japan further. Before coming to Japan, he

\footnotetext{
${ }^{4}$ The term gaijin is a word means "foreigner" but includes discriminative connotations.
} 
thought that advanced Japan was more open to other Asians.

Thao experienced feeling alienated from both classmates and co-workers. He found his Japanese classmates superficially nice but that they seemed to avoid having close relationships with him. He even felt discriminated against. He described what happened:

"The other day, one of my Japanese classmates discussed a topic with me in a friendly manner in class, but after we left the classroom, he acted as if he were a different person. When I ran into him in a different place on campus, I was going to say "Hello!," but as soon as he glanced at me, he clearly ignored me (I am sure our eyes met!) I was perplexed by this incident. Unless a teacher assigns students to work together, Japanese students do not bother to sit and mingle with foreign students, so I am always alone in your class, too, as you can see, while Japanese students are always together with their friends. I want young Japanese people to be more open to other Asians in a real sense; otherwise Japan will not be globalized.

In general, many Japanese students remain indifferent to and ignorant of the outside world. They have become inward-looking. Unless foreign students can speak Japanese fluently, many Japanese students are not interested in making friends with them. As one Japanese student described it: "I really admire their hard work in learning Japanese in addition to English, but I don't know where to begin talking, so I don't bother to talk to them."

Moreover, in Thao's part-time workplace, a Japanese traditional pub, he felt a sense of alienation:

"Japanese peers do not talk to me even during breaks. They are always together talking about something funny. I often hear them laughing loudly. Actually, at first, they were kind and talked to me, but once they found it difficult to have a smooth conversation with me, they gave up talking to me. They just give me a word of greeting when we meet. In addition, one day the manager yelled at me because the number of ice cubes I put in a glass was wrong. I did not know about this rule (the Vietnamese are easy-going, so no one cares about it), but he said he had told me before. But I did not understand why he yelled at me like that. It's just the number of ice cube!! Then, I realized that my Japanese is not good enough for me to achieve a close relationship with them."

Thao initially wanted to improve his Japanese by interacting with Japanese people in his local community, but perversely, he found it difficult to interact with Japanese people without high 
proficiency in Japanese.

Two other participants, $\mathrm{Xia}$ and $\mathrm{Tu}$, also explained the difficulties they experienced in making Japanese friends, reporting that even with a good command of Japanese, it is still difficult for them to understand what Japanese people really think as Japanese people often use tatemae (publicly stated opinions) as well as ambiguous words as they do not want to be seen in a negative light. As a result, they do not show honne (true desires and feelings). Tu, a Taiwanese male student, pointed out that,

"Although I am Taiwanese, my ways of thinking and behavior are rather Western, I think. It is because I lived in different countries because of my father's job and I went to international schools, where I was encouraged to express my opinions without any hesitation or fear about how people think of me. Because of that, I like taking the lead. But in Japan, it does not work. In fact, during a group project in university, when I asked as a leader if the group members had any questions or problems with my management, they said: "No, nothing, thank you, you are doing a great job!", so I completely trusted their statements, kept taking the initiative, and I kept going. But I found out later that they had complained about my leadership behind my back and that they had seen it as a bossy attitude, so they did not bother to argue against me. It was shocking when I learned about it, and I was very frustrated. Since then, I have lost confidence in taking a leadership role in Japanese society, so currently I try to be reserved."

The more these Asian students become familiar with Japanese customs and manners, the more they are disappointed at exclusive, discriminatory, and contradictory Japanese attitudes.

\section{Student Perspectives: Outcomes}

As their sojourns in Japan progressed, the students' perspectives on Japan and Japanese people changed, but they still continue to try to conform to Japanese norms. Yuan started to "keep her head down" in class. She explained this change as follows:

"I tried to be quiet like other Japanese students, and even refrained from expressing my opinions and disagreeing with my teachers because one day I noticed that a teacher seemed annoyed by my occasional rebuttals and questions, and I got a bad grade from the teacher. I thought I had contributed to the class as no students were active and the class was completely dormant. But since then I have changed my attitude towards class."

Currently, even when Yuan encounters conflicting opinions, she tries to shut herself up and just 
keeps a distance from her opponent and behaves like Japanese students, who always sit at the back of the classroom.

In Thao's case, he started to believe that his lack of Japanese proficiency could prevent Japanese people from having good relationships with him. As a result, he also changed his attitude toward dealing with Japanese society. He explained how he changed as follows:

"At first, I was perplexed and frustrated by the behavior of Japanese people, so I got the feeling that I feel more comfortable being with other Asian students, like Chinese and Korean students in school and keeping a distance from Japanese co-workers in my workplace. But recently. I have become accustomed to the narrow-mindedness of Japanese people, and I do not care anymore about it. I changed my mindset. So whenever I am asked, I participate in drinking parties after school and I work to build trusting relationships with Japanese people around me although I'm really, really worried about money and my studies. Maybe I have pushed myself to hard?!"

Drinking parties are typical Japanese custom intended to promote friendship. Even occasional failure to attend such a party gives the impression that you are unsociable. Although Thao became distressed about money as his father sent him only derisory amounts, he was unable to turn down invitations from Japanese people despite the fact that he does not really want to participate in the parties.

Like Yuan, four other participants, Yong-ha, Seung, Xia, and Tu, also have a good command of spoken Japanese. However, unlike Yuan but like Japanese students, they tend to be quiet in class and always use Japanese unless their teachers require them to use English despite the fact that they also have a good command of spoken English. However, they do not show their plurilingual identity in their interactions with Japanese classmates. I asked them the reason for this, and these three participants made a similar remark, explaining that behaving like Japanese people is a good way to avoid being alienated from them and an effective way to have close relationships with them and that they therefore get along well with Japanese classmates.

\section{Student Perspectives: Vision for the Future}

As all participants' narratives demonstrate, they seem under pressure to conform to specific social power and norms in order to join real Japanese society. This results in losing admiration and passion for Japan. All participants expressed the desire to go to another country after 
graduation from a Japanese university, one where racial diversity is promoted and social justice is established. They do not wish to worry about how Japanese people see them but just want to be themselves. Thao described his future plan in assertive terms:

"I don't intend to stay in Japan after my graduation. Before I came to Japan, I really wanted to work for a Japanese company, but now I don't. Currently, I feel like working for a company where people coming from different cultural backgrounds work. Given its diversity and cultural openness, America comes to mind. When I was in Vietnam, I did not like studying English even though my father kept suggesting I should study English. I ignored his suggestion and studied Japanese hard. But now, my interests and passions have changed to America!! I started to watch Hollywood movies to master English. I am earning money through part-time work in Japan to study in America. Then, hopefully, I might be able to get a job there."

Yuan feels the similar way as Thao does. She receives a large scholarship from the Japanese government every month. In return, the Japanese government expects her to make a major contribution to the relationships between Japan and Malaysia once her studies are completed. However, she remarked that,

"I am a Chinese Malaysian. To be honest, this may sound selfish or convenient to me, but I don't have any roots in Malaysia. I don't speak Malay as much as they [the Japanese government interviewers] expect. I feel pressured by the scholarship I earned from the Japanese government. Anyway, I need to find a job that will be a bridge between the two countries. But after that, I would like to return to being a student again in a different country. Sorry, but no more Japan! Ha ha!"

For their part, Xia, Tu, and Yang-han have the ability to behave like Japanese people and have a good command of Japanese, yet they feel uncomfortable living in Japan as foreigners as they have realized that Japan is not as global a society as they expected and Japanese people are exclusive. Consequently, they too have decided not to stay in Japan after their graduation from Japanese university. Their interests also changed to another country.

However, they want to retain or even develop their Japanese language skills as they know that having other language skills in addition to their mother tongue and English will give them an advantage for employment either when they apply to a multinational company or once they go back to their home country. 


\section{Discussion and Implications}

The participants' narratives show there are gaps between what they had imaged about the Japanese and the real Japanese before them. They have come to understand that in addition to prejudices against other Asians, a lack of Japanese proficiency and failure to behave like the Japanese can hinder them from interacting with Japanese people, which ultimately leads to developing a sense of alienation or discrimination. Consequently, although they demonstrate cultural openness, they are under pressure to conform to specific social power, norms, discourses, and systems in order to join Japanese society. Individuals are subjected to these forces, and individual subjectivity is formed through them. This fits Foucault's claim that social power, norms, discourses, and systems determine individual subjectivity. Agency- the ability and will of an actor to act in a given environment- can then be exercised. Ultimately, these students ended up feeling uncomfortable being actors and decided to leave Japan.

Many Japanese people are ignorant of other Asian countries and their cultures. In the context of Japanese university settings, the main focus has been on dominant cultural patterns, specifically the cultures of the English-speaking world. When speaking of the cultivation of global human resources, for instance, almost all Japanese universities prioritize the development of English language competencies, not deepening cultural knowledge and understanding. In effect, most people blindly and unquestioningly accept this status quo and fail to pay close attention to other cultures, especially “periphery cultural realities” (Holliday, 2011, p. 12).

I argue that discrimination and prejudice arise from ignorance. Given this situation, the Top Global University Project initiative and the institutions that favor it should pay more attention to a cosmopolitan pedagogy so that Japanese students can communicate with foreign students as global citizens as opposed to only emphasizing English language competencies. Specifically, we as educators should encourage students to address human rights issues and facilitate the development of a concern for social justice in our communities first and then at national and

global levels. For this purpose, the notion of cosmopolitanism should be taught as the object of classes. Then we should create a learning experience in which students can discuss human rights issues at local and global levels while engaging in critical self-reflection. Such a cosmopolitan pedagogy may help Japanese students develop an openness to cultural differences and grow to be global citizens in a real sense. 
Finally, my participants' narratives indicate that Norton's (2013) argument that where there are unequal power relations between language learners and target-language speakers language learners' commitment to learning the target language is discouraged turns out not to be consistent with the findings of this research. This study found that even if they experience unequal power relations between themselves and Japanese people, my participants still invest in the Japanese language with a sense of superiority about their English competence compared to that of many Japanese students and with the understanding that the Japanese language will add value to them, or what is termed "cultural capital" by Bourdieu and Passeron (1977), rather than solely aspiring to Japanese technology, a dimension that needs exploring in future studies.

\section{Statements of ethics and conflict of interest}

"I, as the Corresponding Author, declare and undertake that in the study titled as "The Formation of Subjectivity in Asian Students in Japanese Higher Education”, scientific, ethical and citation rules were followed; Turkish Online Journal of Qualitative Inquiry Journal Editorial Board has no responsibility for all ethical violations to be encountered, that all responsibility belongs to the author/s and that this study has not been sent to any other academic publication platform for evaluation."

\section{References}

Benson, P., Barkhuizen, G., Bodycott, P., \& Brown, J. (2012). Study-abroad and the development of second language identities. Applied Linguistics Review 3(1), 173-193.

Benson, P., Barkhuizen, G., Bodycott, P., \& Brown, J. (2013). Second language identity in narratives of Study Abroad. London: Palgrave Macmillan.

Block, D. (2006). Multilingual identities in a global city: London Stories. London: Palgrave Macmillan.

Bourdieu, P., \& Passeron, J.C. (1977). Reproduction in education, society, and culture (R. Nice, Trans.). London: Sage.

Churchill, E. (2009). Gender and language learning at home and abroad. JALT Journal, 32, 141158. 
Cohen, L., Manion, L., \& Morrison, K. (2011). Research methods in education ( $7^{\text {th }}$ ed.). London: Routledge.

East Asia Forum (2014, December 30). Japanese universities reach for global status. Retrieved from: http://www.eastasiaforum.org/2014/12/30/japanese-universities-reach- for-globalstatus

Foucault, M. (1980). Power and knowledge: Selected interviews and other writings 1972- 1977. New York: Vintage Book.

Foucault, M. (1982). The subject and power. Critical Inquiry, 8(4), 777-795.

Gall, M.D., Gall, J.P., \& Borg, W.T. (2003). Educational research (7 ${ }^{\text {th }}$ ed.). White Plains, NY: Pearson Education.

Holliday, A. (2011). Intercultural communication and ideology. London: Sage.

Jackson, J. (2008). Language, identity, and study-abroad: Sociocultural perspectives. London: Equinox.

Lather, P. (1992). Critical frames in educational research: Feminist and post-structural perspectives. Theory into Practice, 3(2), 87-99.

Merriam, S. B. (2002). Introduction to qualitative research. In S. B. Merriam et al. (Eds.), Qualitative research in practice: Examples for discussion and analysis (pp. 3-17). San Francisco, CA: Jossey-Bass.

MEXT. (n.d.). The Global University Project. Retrieved from https://www.mext.go.jp/en/policy/education/highered/title02/detail02/sdetail02/139542 $0 . \mathrm{h} \mathrm{tm}$

Nagatomo, D. H. (2012). Exploring Japanese university English teachers' professional identity. Bristol: Multilingual Matters.

Norton, N. (2013). Identity and language learning. Bristol: Multilingual Matters.

Piller, I., \& Takahashi, K. (2006). A passion for English: Desire and the language market. In A. Pavlenko (Ed.), Bilingual minds: Emotional experience, expression and representation, (pp. 59-83). Clevedon: Multilingual Matters.

Polkinghorne, D. E. (1995). Narrative configuration in qualitative analysis. Qualitative Studies in Education, 8(1), 5-23.

Riessman, C. K. (2008). Narrative methods for the human sciences. Thousand Oaks, CA: Sage.

Sato. T. (2014). The effects of study-abroad on second language identities and language learning. Turkish Online Journal of Qualitative Inquiry, 5(3), 28-41. 
Sato. T. (2015). Second language identity and social structuring: The construction and social structuring of second language identity through study-abroad. Saarbrücken: Lap Lambert.

Scott, J. (1990). A matter of record: documentary sources in social research. Cambridge: Polity Press.

Seidman, I. (2006). Interviewing as qualitative research: A guide for researchers in education and the social sciences ( $3^{\text {rd }}$ edition). New York: Teachers College Press.

Simon, M., \& Goes, J. (n.d.). Reliability and validity in qualitative studies. Retrieved from https://www.dissertationrecipes.com/reliability-validity-qualitative-studies/

Sobré-Denton, M., \& Bardhan, N. (2013). Cultivating cosmopolitanism for intercultural communication: Communicating as global citizens. New York: Routledge.

Thomas, G. (2013). How to do your research project: A guide for students in education and applied social sciences ( $2^{\text {nd }}$ ed.). London: SAGE. 